\title{
CREATION OF SOCIAL INNOVATION IN RURAL AREAS
}

\author{
Aistė Ragauskaitè, Jan Žukovskis \\ Vytautas Magnus University, Lithuania \\ aiste.ragauskaite@vdu.lt
}

\begin{abstract}
Social innovations are recognized as one of the most promising innovations in solving social problems in rural areas. When assessing the creation of social innovation, it should be noted that not only the goal and the result but also the whole process of creation of social innovation is important. The analysis of theoretical and practical research has revealed that traditional methods of solving problems in rural areas are not working, which consequently leads to search for innovative solutions. The most obvious social problems in rural areas, such as an aging society, youth departure, lack of breakthrough and innovative ideas, etc. can be noticed when assessing factors of social environment. At this stage, the solutions sought through the prism of social innovation can become those that will ensure the wellbeing of the rural area and support people living there. Social innovation is widely spread at the level of the European Union; however, in Lithuania, social innovation is taking just the first steps. The article analyses the case of Sèlyne village in Rokiškis region, during which social innovation that succeeded to unite rural community has been created. The article aims to analyse the process of creation of social innovation in rural areas from the theoretical point of view and to present the case of Sèlynè village of Rokiškis region. The main problem is the complex understanding of the creation process of social innovation.
\end{abstract}

Key words: social innovation, rural areas, creation, inclusion.

\section{Introduction}

Rural areas are those regions that receive great attention today and are assessed through the search of their growth and breakthrough. Scientists also focus on social innovation in rural areas and search for its effective development and creation. Social entrepreneurship is one of the elements through which social innovation could likely be developed; however, in order for social entrepreneurs to create social innovation, people should clearly understand both the very concept of social innovation and the process of its creation adapted to the rural area.

The analysis of the process of creation of social innovation in rural areas from the theoretical point of view and introduction of the case of Sèlynè village of Rokiškis region is the aim of the research.

Social innovation is generally defined as the generation and implementation of new ideas about how people should organize interpersonal relationship or social interactions with the aim to meet common goals (Marcy et al., 2007; Mumford, 2002). According to Phill et al. (2008), social innovation is not just a product, a process or a technology, but it can also be a principle, an idea, a piece of legislation, a social movement, an intervention or some combination of them. However, Moulaert et al. (2013) emphasizes that social innovation is not associated with certain products or achievements but relates to the process of creation of innovative social relationship between individuals and their groups (Moulaert et al., 2013). Social innovation has become an alternative to complex and expensive innovation and is considered even more efficient and more influential in the scientific sources.

The concept of social innovation has not been always identical. The definitions of social innovation of the most significant authors are given in Table 1 .

The concept of social innovation (compiled by the author of the article)

Table 1

\begin{tabular}{|l|l|}
\hline \multicolumn{1}{|c|}{ Scientific source } & \multicolumn{1}{c|}{ Statements } \\
\hline Tanimoto et al., 2007 & $\begin{array}{l}\text { Social innovation is defined as improved activities, initiatives, services or processes to solve } \\
\text { economic and social challenges faced by individuals and communities. }\end{array}$ \\
\hline Heiscala, 2007 & $\begin{array}{l}\text { Social innovation refers to changes in the cultural, legal and regulative structures of a society that } \\
\text { both increase collective power resources and improve economic and social performance. }\end{array}$ \\
\hline Pol, 2009 & $\begin{array}{l}\text { Social innovation refers to innovative activities resulting from a response to a social need or } \\
\text { improvement of life quality that can be spread through different organizations. }\end{array}$ \\
\hline Caulier-Grice, 2012 & $\begin{array}{l}\text { Social innovation refers to new solutions (products, services, models, markets, processes, etc.) } \\
\text { that simultaneously meet social needs (more effectively than alternatives), also new opportunities, } \\
\text { relationships or a better use of resources. Social innovation is focused on the enhancement of the } \\
\text { society's capacity to act. }\end{array}$ \\
\hline Matei et al., 2015 & $\begin{array}{l}\text { Social innovation is a development of new ideas (products, services, models) to meet the } \\
\text { unfulfilled social needs. Social innovation should be especially promoted in public sector, } \\
\text { community groups or other public organizations. }\end{array}$ \\
\hline
\end{tabular}


Having evaluated the development of the concepts of social innovation, the following can be noted: social innovation is focused on the fulfilment of social needs through different types of social innovation involving the people concerned. Moreover, researchers have identified three core dimensions of social innovation, which are as follows: satisfaction of human needs (content dimension); changes in social relations especially with regard to governance (process dimension); and increase in the socio-political capacity and access to resources (empowerment dimension) (Gerometta, Hausermann, \& Longo, 2005).

A group of researchers Moulaert et al. (2005) analysed social innovation in 2005 with the aim to distinguish social innovation from innovation but used the key innovation elements to identify social innovation. A comprehensive analysis of social innovation, including the distinction of their types, identification of dimensions, cross-sectoral analysis and evaluation of results and processes was performed in later studies only during the period from 2007 to 2016 (Matei, 2015; Moulaert et al., 2005; Neumier, 2012). According to Dainiene et al. (2015), the interest in social innovation has started to increase since around 2000. The interest has grown as a result of the increasing need to analyse and overcome social challenges. Innovation focused on social problems includes social innovation, and institutions are one of the main participants in the process of social innovation. The introduction of social innovation has led to the introduction of clear types and classification of innovation. Since the biggest attention is paid to technological innovation which does not solve welfare problems, but can be measured and has a clear result, in scientific literature more attention is paid to the need of social innovation through the social perspective. According to the classical definition, a village is a little urbanized area surrounded by natural environment and has a low concentration of population (Vaznonis \& Čiūtaitè, 2010). Atkočiūnienè (2008) has a similar opinion and says that a village is a territorial system characterized by natural environment and a small concentration of population forming territorial rural communities.

Rural areas in modern communities often come across with certain social and economic challenges. Čepienè (2011) emphasizes that rural communities often face with increasing social problems, such as poverty, unemployment, social exclusion and migration related problems that become relevant for both the individual and the entire rural community. Leliūgiene (2010) also highlights similar problems in rural communities: migration from one country to another, job search in other countries, unemployment, poverty, violence in society, growth of crime rate and addiction diseases. Business companies generally concentrate in cities and urbanized areas; therefore, there is a relatively high level of unemployment in rural areas. Unemployment and a lack of employment do not only cause financial difficulties, but also psychological problems: jobless people often feel frustrated and internal discomfort and those who fail to deal with a lack of employment start using alcohol, drugs and commit crimes (Mooney et al., 2014). Kazakevičius (2004) is of the same opinion and claims that people living in villages face with low employment and get low income which consequently result in a decline of life quality, also economic and social problems, such as poverty, unemployment, alcoholism, social exclusion, increased crime rates, increased number of children not attending schools, abandoned children, also socially and pedagogically abandoned children. It should be noted that rural communities come across with a huge amount of economic and social problems, which directly affect many members of rural community.

Social innovation can encourage changes of the people concerned to create social and power relations among the members of a certain community, affect governance principles and promote collective activities. Social innovation is grouped as process innovation. When there is a change in the inclusion models for the people concerned, a result of other social innovation is likely to happen. It is also necessary to emphasize that social innovation enables the society to participate in significant processes more actively; therefore, a change in the main governing structures is likely to happen by giving additional opportunities to the society (Moulaert et al., (2013). Neumier (2012) is one of the first researchers who has started to study the impact of social innovation on the process of rural development. The researcher found out that social innovation, contrary to technological innovation, generally integrates into the processes of rural development more effectively and better involves participants, such as public and private sectors, also the sector of the people concerned. According to Neumier (2012), the creation of social innovation starts from the identification of the problem. In the opinion of the aforementioned researcher, the idea or identification of the problem by the people concerned, e.g. a new rural development program, etc. can be the initial impulse for innovation. It is then followed by the expression of interests, i.e. the change of behaviour or attitude focused on the change as common interest. Later on, the solutions are made, and collaboration is carried out. A group of people concerned decides to make essential changes and adopts new conditions.

While assessing various models of creation of social innovation and considering this process in rural areas, a model of social innovation in the rural area with extended actions and results has been made. 


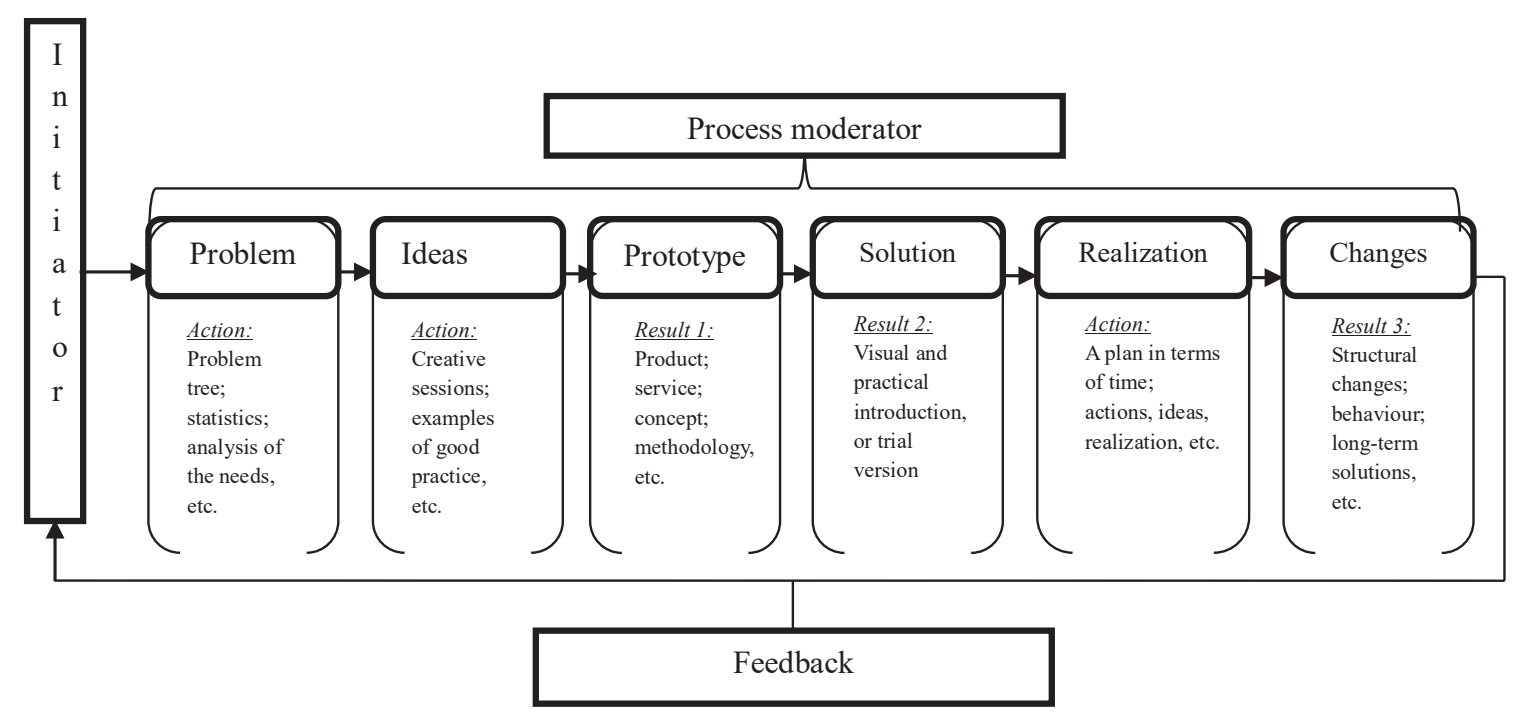

Figure 1. Creation of social innovation in rural areas.

The creation of social innovation is relatively consequent and structured. However, attention should be paid to the disclosure of each stage and actions made at that stage. The initiator is needed to start the process in the rural area. He can be a local leader of the community or an active member of the community who can motivate others to undertake actions. It should be also noted that a process moderator plays a significant role in the creation of the process, who can be the same process initiator or another active public leader. Different actions focused on the best result of the stage are made at each stage. A feedback can be also used for the evaluation of the result, the target recipient of which is the initiator of the creation of social innovation. This creation of social innovation is focused on the human capital, which is usually very strong in the rural area.

\section{Materials and Methods}

An interview as a qualitative research method has been chosen for the study. Socially sensitive issues of social innovation can be analysed by both quantitative and qualitative research methods; however, qualitative research methods are usually chosen in practice (Žydžiūnatè, 2017; Kardelis, 2016). The fact that social innovation is highly affected by the human capital in rural areas is also considered. Social leaders are often distinguished during the process of creation and are the main catalysts of the entire process of social innovation in the rural area. Also, a qualitative research method an interview has been chosen because of a small rural community, which is distinguished for its especially strong social relationship and great inclusion of the society in the ongoing processes.

Introduction of the case of Sèlyne village where social innovation started to be developed is the aim of the empirical research.
There is a small community in Sèlyne village in Rokiškis region, which organizes various educational activities, events and other community gatherings. The community has started the realization of social innovation related to competence sharing since 2017. There are 150 residents and 30 members of the community in Sèlyne village; therefore, a convenient selection has been made and the most active ten members of the community have been selected for the interview. The interview consisted of ten questions including such issues as demographic situation, the main principles for the existence of the community and also research questions according to the model of creation of social innovation in the rural area. The interview focused on the evaluation of social innovation related to the system of competence sharing. The research was made in November 2018. One hour and a half was the average duration of the interview with each respondent. The respondents by gender are as follows: 8 women and 2 men. The average age of respondents was 42 years. Respondents are also active members of the community. Confidentiality has been preserved during the survey. The data of the respondents are summarized and systematized according to the research questions. The answers of the respondents are coded from R1 to R10. The respondents were notified about the process and the purpose of the research in advance. The aim of the research and the competence of the researcher to do a research in this field have been introduced to the respondents in advance.

It can be said that the extent of the researched group is enough to define the main principles of social innovation, which is in the process of creation in Sèlynè village in Rokiškis region. Moreover, based on the provisions of the study, the methodology, and proposals of the respondents, the cases of creation 
of other social innovation can be also researched. The main risk of the study was associated with the emerging active community in Sèlyne village, which has little experience in the creation of social innovation. Nevertheless, a huge interest of the active part of the community and motivation to develop social innovation in the rural area has been noticed.

\section{Results and Discussion}

A successful development of rural areas depends on the activity of local groups and communities, and also on the inclusion of locals in fostering the rural area. Although the activities of local groups are not spread evenly (some are more active, others are passive), but the further the more innovative solutions of the community involving other members of the community can be noticed. That is why phenomena, such as social initiatives, social innovation and social entrepreneurship are emerging. However, the research in Rokiškis region has revealed that community organizations feel a lack of the following: knowledge about social innovation; creativity to create social innovation; there is a fear to create social entrepreneurship; trust in oneself and other community members; examples of good practice; and versatile management skills and competences. All these aforementioned factors are the main reason why there is such a slow access to social entrepreneurship and the stage of realization of social innovation is the most typical in the researched area. Yet, a tendency has been observed that the current EU funding for communities is directed towards the promotion of entrepreneurship of communities. The case of Sèlyne village in Rokiškis region will be further analysed below.

Situation. There are 150 residents and an active community in Sèlynè village. A local library, which is still open in the village, is the main place of the community gathering. Most often, the effectiveness of the whole initiative and community depends on the leader of the community. A social initiative (inclusion of rural residents who have left the village into the activities of the community) has been started in the community of Sèlyne village. The program is called the "Synergy of experiences". The main model of social initiative works through the inclusion of grown-up children who return to the village to visit their parents. Most often, grown-up children of the village move to some bigger cities and return to the village just to visit their parents. Thanks to active rural community, the returning grown-up children were offered to share their experience in the organization of activities in the rural community. The social innovation, which has been created in the community has encouraged the members of the community to actively involve the youth who no longer live in the village. Each person, who is involved in the activities according to his/her competences, which they have gained after they left the village, can share their experience with the community of the village in both organization of festivals, training and teaching other community members. Organization of the 'Festival of the blossom of Sèlyne village' is one of the best examples, which included marketing, publicity and creation of the concept of the event. And everything was made by the youth who no longer live in the village. Also, training and sharing knowledge, e.g. training in the management of social networks and communication, which was free of charge to the community attracted not only a great number of locals, but also people from other villages. Based on this program, there are plans to further involve more youth who have left the village and who would help to generate entrepreneurial ideas, prepare applications for projects and educational activities. A significant fact should be noted that all these activities are carried out without funding and are free of charge to the community. In this way, a close social relation among the members of the community who still live in the village and those who have already left the village, but still carry out activities in their village, is maintained.

Initiator's profile. According to the respondents, the initiator is especially significant, and she was one of the main initiators to promote the social innovation in Sèlynè. Yet, the respondents admit that it would be perfect to have one permanent leader who would direct the activities and encourage other community members.

Process moderator. According to the respondents, the program the 'Synergy of experiences' also highly depended on the moderator of the whole process. The role of the process moderator was especially significant at the stage of the idea and realization. The respondents noted they felt a close cooperation between the initiator and the moderator in the creation of the competence of social innovation.

Problem. A local action group of Rokiškis region precisely indicates all the problems of the region in its strategy, but the residents of the rural area were asked to evaluate the main problems on the Likert scale from 1 (a very little problem) to 5 (a huge problem). 'Mostly we feel we are an old village. The residents are of older age, while grown-up children moved to bigger cities,' says the respondent R2. A comment of one active member of the community about a lack of funding can be added to the aforementioned opinion. According to R4, 'most probably, we have ideas, but there is a lack of finance. Some initiatives are funded by the members of the community, but if we have bigger purchases, we need to prepare projects, but we do not know how to prepare them'. The respondents also emphasized that they are willingly waiting for the return of the youth, who can bring and share their latest 


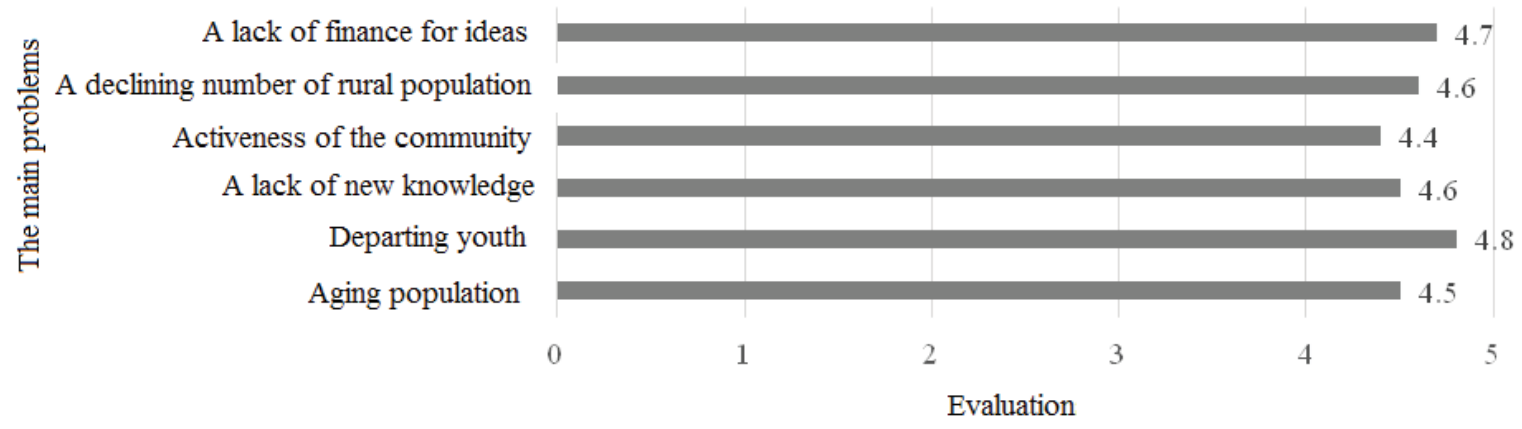

Figure 2. The main problems in rural areas $(\mathrm{N}=10)$.

knowledge, because the members of the community do not know about the latest trends and also have a lack of competence, which can be gained in the bigger cities. Bigger cities can offer the abundance of training or seminars, while in rural areas they are organized rarely. The respondents agreed that the problems cannot be easily solved, but creative solutions should be searched for.

Ideas. The aim of this question was to find out what principle is used to develop the ideas for solving a particular problem. According to the respondents, the problems are obvious, and therefore sometimes ideas arise extemporaneously, and they are sometimes generated during the meetings, and are rectified and elaborated. According to the respondent R6, 'the idea of synergy of experiences arose during the discussion, when it was considered what interesting activities can be organized for the community and how to attract more members of the community'. The theoretical part also analyses that creative sessions and other activities that stimulate the initial thoughts for generating the problem are suitable for generation of ideas.

Prototype. In case of the 'Synergy of experiences', the concept has been developed that provides goals, objectives and core activities. According to the respondent $\mathrm{R} 5$ and respondent $\mathrm{R} 8$, both the initiator and the process moderator worked on the fulfilment of the concept, and other community members only got involved in the process in the next steps. It can be seen that two responsible people are enough to develop the idea, and other people concerned can be involved when more work needs to be done. In this case, most of the respondents who participated in the interview supported this observation.

Solution. The solution of the 'Synergy of experiences' along with the visualization has been presented to the members of the community during the first event. According to the respondents who participated in the study, there was a clear interest of most members of the community and their willingness to contribute. Three main members of the community took the role of leaders. They have also distributed activities and offered their help in distributing and sharing work. It was important for other members of the community to get involved, but they did not want to take the initiative. According to the respondent R2, people are used to have a leader who leads the whole work, while other people do the job. A similar situation is in this project, where most people are waiting for someone to tell what they should do, because they do not want to take the lead. This observation can be supplemented with a statement of the respondent R3 that Sèlyne village does not have one and single leader. Someone usually takes a role of an initiator who initiates, generates ideas and acts. And next time there can be another initiator who will initiate other activities. There is, therefore, a serious lack of systematic arrangements. In scientific works, which analyse rural areas, it is noted that a role of social leader, who could unite and motivate locals or even show an example to others, is especially important in these locations where close social relationship is a common thing.

Realization. It is one of the main stages in which most members of the community get involved. The respondents, however, have been asked, in connection with this question, to assess the most common disturbances that interfere with performance and which impede the smooth implementation of the idea. The statements were assessed in a Likert scale from 1 (absolutely does not interfere) to 5 (very much interferes). According to the respondents, a lack of a clear vision is the matter that is the most interfering with the implementation of ideas. According to the respondent R3, 'it sometimes seems that we manage to reach a consensus, and discuss the idea, but later, when we start to work, leaders willing to fundamentally change everything appear. This makes people confused'. It can also be noticed that work sharing is another disturbance identified by the respondents. According to the respondent $\mathrm{R} 1$, 'you can sometimes understand that there were many people who wanted to do something, but they disappear when it comes to work leaving only few enthusiasts to do the whole work'. Planning of works is one of the main disturbances. It was described by 


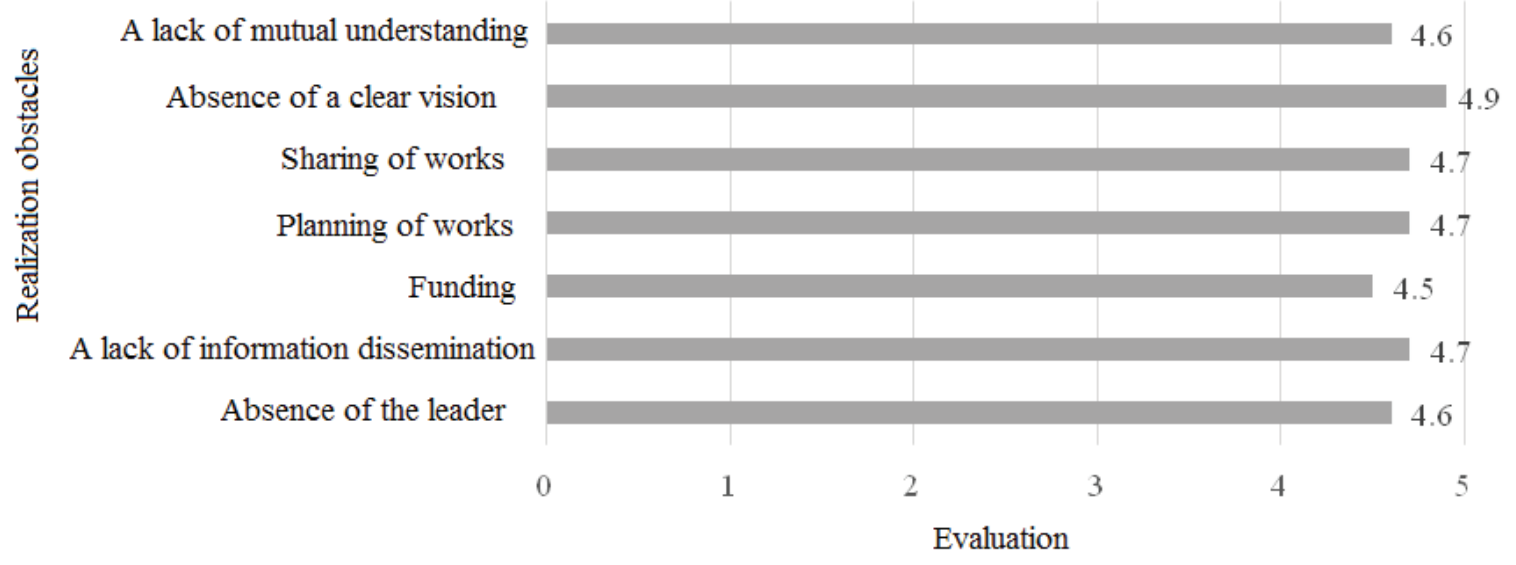

Figure 3. The main realization obstacles $(\mathrm{N}=10)$.

the most respondents as phenomenon of 'the last night' that is very common among many people, who skip preparatory works. Absence of information dissemination is another key disturbance. Although not many people reside in Sèlynè village, and there are very few members of the community, it sometimes seems that only the most active members are aware about the activities organised (the opinion expressed by R1, R4, R3, R7).

Changes. One of the stages of creating social innovation that shows whether social innovation is short-term or long-term, and what changes it has made in a rural area. As most respondents say, the 'Synergy of experiences' forced everyone to communicate with their loved ones, whether or not they could bring their competences to a rural area and share them with the community. According to R4, 'I have never asked my children for anything in the past. But now our good experience already shows that you only have to offer others to do something and they always agree'. Most of the respondents added that all young people get involved voluntary and they willingly contribute to community building. According to R6, the initial activities led to thinking about future activities that will focus on training and knowledge transfer in business creation, economic literacy, project preparation, etc. Although the 'Synergy of experiences' means the activities that are not fully structured, the statements of the respondents during the interviews suggested that this social innovation, that started a year ago, is characterized by great vitality.

Feedback. In order to find out whether the social innovation developed has proved to be beneficial, it is expedient to collect feedback. According to the respondents, in this particular case they trusted in feedback that is passed by word of mouth and collected no feedback. Opinions and experiencebased assessment of young people who got involved in the activities have been assessed. A continuity of the social innovation the 'Synergy of experiences' has been also ensured through enthusiastic involvement of the members of the community.

Sèlyne village in Rokiškis region was selected for the case study. Young community of the village has developed the first social innovation, i.e. the 'Synergy of experiences'. The interview method that was used during the study revealed the opinion of the most active members of the community about the creation of social innovation in the rural area. The whole process produced both positive and negative experiences, the members of the community managed to identify the stages of each process, as well as the factors at the stage and the obvious directions of improvement.

\section{Conclusions}

Little research still has been done on the subject of the creation of social innovation in rural areas. However, social innovation, creation and rural areas, as separate elements, are analysed quite extensively. The theoretical analysis revealed that the community is the main factor in the rural environment, and there is a close social relationship between people who live in a rural area. Social innovation can become a solution to many persistent problems in the rural area that are difficult to solve. Consequently, the process of creation of social innovation in rural areas should be analysed in further studies at each stage throughout the development process.

Creating social innovation is a sensitive process and, as shown by the case study of one community that is based on interviews with respondents about the social innovation created, the process itself must be consistent. However, several critical moments become evident in each stage. During the process of creation of social innovation, the community also often faces the internal problems and encounters disturbances. It is also important to assess the inner synergy of the members of the community who are stimulated to act by interesting activities they are engaged in. 


\section{References}

1. Atkočiūnienè, V. (2008). Kaimo vietovès pokyčių valdymas pagal principą 'iš apačios ị viršų' (Management of rural change from bottom to bottom). Ekonomika ir vadyba. No. 2 (11), 6-14. (in Lithuanian)

2. Caulier-Grice, J., Davies, A., Patrick, R., \& Norman, W. (2012). Defining Social Innovation. A deliverable of the project: 'The theoretical, empirical and policy foundations for building social innovation in Europe' (TEPSIE), European Commission $-7^{\text {th }}$ Framework Programme, Brussels: European Commission, DG Research, 16-23.

3. Čepiené, A. (2011). Kaimo bendruomenès narių socialinio dalyvavimo teorinès ịžvalgos (Theoretical insights of social participation of rural community members). Profesinès studijos: teorija ir praktika 2011/ 8, 124-130. Retrieved March 9, 2019, from https://ec.europa.eu/epale/sites/epale/files/2014-epale1t-00128.pdf. (in Lithuanian)

4. Dainienè, R., \& Dagilienè, L. (2015). A TBL Approach Based Theoretical Framework for Measurink Social Innovations. Social and Behavioral Sciences, 275-280. DOI: 10.1016/j.sbspro.2015.11.537.

5. Gerometta, J., Haussermann, H., \& Longo, J. (2005). Social innovation and civil society in urban governance: strategies for an inclusive city, Urban Studies., 42, 11, 2007-2021. DOI: 10.1080/00420980500279851.

6. Heiscala, R. (2007). Social innovations: structural and power perspectives, 52-79. Retrieved March 9, 2019, from https://www.researchgate.net/publication/290940850.

7. Kardelis, K. (2016). Mokslinių tyrimų metodologija ir metodai (Research methodology and methods). Mokslo ir enciklopedijų leidybos centras, 32-45. Vilnius. (in Lithuanian)

8. Kazakevičius, Z. (2004). Kaimo gyventojų užimtumas ir jo didinimo galimybès (Employment of rural population and opportunities for its increase). Kaimo verslų vadyba: teorija, studijos, praktika. Kaunas: Lietuvos žemès ūkio universitetas, 112-128. (in Lithuanian).

9. Leliūgienè, I. (2010). Lietuvos bendruomenių vystymo perspektyvos tarptautinès patirties kontekste (Development perspectives of Lithuanian communities in the context of international experience). Konferencija 'Vietos savivalda ir bendruomenès Lietuvoje' 73-83, Vilnius. (in Lithuanian)

10. MacCallum, D., Moulaert, F., Hillier, J., \& Haddock, S., (eds.). (2009). Social innovation and territorial development. Ashgate, Farnham, 11-23.

11. Marcy, R.T., \& Mumford, M.D. (2007). Social innovation: Enhancing creative performance through causal analysis. Creativity Research Journal, 19, 123-140. DOI: 10.1080/10400410701397180.

12. Matei, A., \& Antonie, C. (2015). Complexity Theory and the Development of the Social Innovation Procedia - Social and Behavioral Sciences 185, 61-66. DOI: 10.1016/j.sbspro.2015.03.371.

13. Moulaert, F., Martinelli, F., Swyngedouw, E., \& Gonzalez S. (2005). Towards alternative model(s) of local innovation, Urban Stud. 42, 1969-1990. DOI: 10.1080=00420980500279893.

14. Mooney, L., Knox, D., \& Schacht, C. (2014). Understanding Social Problems. Belmont, Cengage Learning, 73-74.

15. Mumford, M.D. (2002). Social innovation: ten cases from Benjamin Franklin, Creativity. Research Journal. 14, 253-266. DOI: 10.1207/S15326934CRJ1402_11.

16. Murray, R., Caulier-Grice, J., \& Mulgan, G. (2010). The open book of social innovation, 1-117. Retrieved March 9, 2019, from http://kwasnicki.prawo.uni.wroc.pl/pliki/Social_Innovator_020310.pdf.

17. Moulaert, F., MacCallum, D., Mehmood, A., \& Hamdocuch, A. (2013). The international handbook of social innovation. Cheltenham: Edgar Elgar, 6-13.

18. Neumeier, S. (2012). Why do social innovations in rural development matter and should they be considered more seriously in rural development research? - Proposal for a stronger focus on social innovations in rural development research, Sociol. Rural. 52, 48-69. DOI: 10.1111/j.1467-9523.2011.00553.x.

19. Phills, J.A., Deiglmeier, K., \& Miller, D.T. (2008). Rediscovering Social Innovation, Stanford Social Innovation Review, 6, 1-11.

20. Pol, E., \& Ville, S. (2009). Social innovation: Buzz word or enduring term? The Journal of SocioEconomics. 38, 878-885. DOI: 10.1016/j.socec.2009.02.011.

21. Tanimoto, K., \& Doi, M. (2007). Social innovation cluster in action: a case study of the San Francisco Bay Area. Hitotsubashi Journal of Commerce and Management, 41(1). DOI: 10.15057/14619.

22. Vaznonis, V., \& Čiūtaite, D. (2010). Kaimo vietovių ekonominio konkurencingumo ir vietos gyventojų verslumo sąsajos (Links between the economic competitiveness of rural areas and the entrepreneurial spirit of the local population). Management theory and studies for rural business and infrastructure development, No. 22 (3), 112-125. (in Lithuanian)

23. Žydžiūnaite, V., \& Sabaliauskas, S. (2017). Kokybiniai tyrimai principai ir metodai (Qualitative research principles and methods). Leidykla Vaga, 62-67. Vilnius. (in Lithuanian) 